\title{
The Effectiveness of Restorative Justice Practice in Bangladesh: An Analysis
}

\author{
Md. Abdul Kader Miah ${ }^{1}$, Mahmuda Akter ${ }^{1}$, Md. Kamruzzaman ${ }^{2, *}$ \\ ${ }^{1}$ Department of Criminology and Police Science, Mawlana Bhashani Science and Technology University, Tangail, Bangladesh \\ ${ }^{2}$ Department of Victimology and Restorative Justice, Institute of Social Welfare and Research, University of Dhaka, Dhaka, Bangladesh
}

\section{Email address:}

makcps@gmail.com (Md. A. K. Miah), shohag.mbstu.cps@gmail.com (Md. Kamruzzaman), mahmudaakterhappy72@gmail.com (M. Akter) ${ }^{*}$ Corresponding author

\section{To cite this article:}

Md. Abdul Kader Miah, Mahmuda Akter, Md. Kamruzzaman. The Effectiveness of Restorative Justice Practice in Bangladesh: An Analysis. Humanities and Social Sciences. Vol. 5, No. 5, 2017, pp. 176-183. doi: 10.11648/j.hss.20170505.13

Received: August 26, 2017; Accepted: September 18, 2017; Published: September 28, 2017

\begin{abstract}
Restorative justice is an innovative movement in the field of victimology and criminology. The formal judicial system of Bangladesh is very expensive and follows a lengthy procedure for the lack of financial resources and outdated legislation pose. Majority of middle class people therefore prefer or rather have no choice but to use the traditional justice mechanisms like restorative justice. This study was an effort to find out how restorative justice could be an effective method for dispute resolution to reduce the backlog and future case loads in Bangladesh. Besides, the core challenges of successful Restorative Justice and some prevention policies to recover drawbacks of the restorative justice in Bangladesh were also studied. As the nature of the research is qualitative in nature, data and information had collected from secondary sources. This study found that, the most important challenge of restorative justice in Bangladesh is the huge backlog of cases, relative ignorance and lack of confidence and legal awareness of the service seekers and providers, lack of monitoring and supervision of the court activities, negative attitudes and perceptions towards legal institutes and absence of legal aid and support. Though the Village Courts have limitations and drawbacks but still it is playing an important role in the settlements disputes and maintaining social peace and tranquility in the rural area. This study argues for the necessary amendments of the village court act, proper monitoring and supervision of the government, resources and preparedness as well as the responsiveness of all stakeholders that can ensure effective restorative justice in Bangladesh.
\end{abstract}

Keywords: Restorative Justice, Backlog Cases, Limited Jurisdiction, Village Court

\section{Introduction}

Restorative justice is an innovative movement in the field of victimology and criminology. Acknowledging that crime causes injury to people and communities, it insists that justice repair those injuries and that the parties be permitted to participate in that process. Restorative justice programs, therefore, enable the victim, the offender and affected members of the community to be directly involved in responding to the crime. They become central to the criminal justice process, with governmental and legal professionals serving as facilitators of a system that aims at offender accountability, reparation to the victim and full participation by the victim, offender and community (Shekhar, 2002). The restorative process of involving all parties often in face-to- face meetings is a powerful way of addressing not only the material and physical injuries caused by crime, but the social, psychological and relational injuries as well (Hassan, 2006).

Over the last two decades, restorative justice has emerged in varied guises, with different names, and in many countries. Current activity at governmental and community levels suggests that restorative justice, in its many forms, is emerging as an increasingly important element in mainstream criminological practice. Interestingly, one kind of restorative justice in the form of village courts has long been prevalent in Bangladesh which has a long history of informal dispute resolution mechanisms with a varying degree of procedures the traditional shalish and the village court (Khan and Rahman, 2009).

According to Morris and Maxwell (2004), restorative justice was first used to refer to certain principles arising out 
of early experiments in America using mediation between victims and offenders. Restorative justice is not a single academic theory of crime or justice, but represents, in a more or less eclectic way, the accretion of actual experience in working successfully with particular crime problems. Moreover, restorative justice practices have been extremely varied (including victim-support, mediation, conferencing, problem-oriented policing and both community and institution-based rehabilitation programs), which innovations were based on recognition of the need for engagement between two or more of the various parties.

Lack of financial resources and outdated legislation pose serious challenges for the judicial system in Bangladesh. Insufficient cooperation of the relevant authorities is leading to an enormous backlog of cases. Our formal justice system is overburdened with pending cases. A few years ago, as per Law Commission report, the total number of pending cases in different Courts of Bangladesh was 19, 13,633 in 1 January, 2010 and in 2009 a number of 7, 19,770 cases were settled following the formal procedure. Examining data from the Courts of Dhaka and Gazipur districts the report also mentioned that, the rate of settling civil cases by means of alternative means was $0 \%$ to $2.5 \%$ of the total cases filed. The Law Commission in their report asserted its concern over this large number of pending cases and urged to take immediate steps for Alternative Dispute Resolution (ADR) (Khan and Rahman, 2009). Moreover, the apex court settled 9992 cases last year and 5991 in 2014. Some 14, 26,676 cases were settled at courts across the country last year, the figure was 13, 04544 in 2014. The number of cases pending with the courts stood at 3,109,860 as of December, 2014 according to the SC study report. Most importantly, approximately 40,000 judges are required to deal with the current backlog cases while 100-200 new judges should be appointed every year. Such a huge backlog of cases shattered the access to justice for common people substantially. Now, the number of total pending case lying with the High Court division till March 31, 2016 were 3,99,303 (BSS, June 16, 2016). As of now, a huge backlog of around 2.3 million cases is pending with the courts across the country including the Appellate Division and High Court Division of the Supreme Court (SC). Disposing of these cases is a hard job for the judiciary with only seven judges for the Appellate Division, 97 judges for the High Court Division and around 1,600 judges for the lower courts across the country. This could have been avoided if restorative justice processes were being implemented in the country (The Daily Star, June 8, 2013).

In order to get rid of the situation activating village courts could be a very effective option as a form of restorative justice. In viewing with this the village court system has been introduced in order to accelerate the justice system by correcting the Village Courts Ordinance, 1976. The basic legal framework for the "Village Courts" is the Village Courts Act, 2006 (Act No. XIX of 2006). The Government of Bangladesh has passed the Village Court Act 2006 which is amended in September 2013 that empowers Union Parishads to resolve disputes that fall under the jurisdiction of the
Village Court Act in an attempt to devolve justice down to the community level. A Village Court can deal with both criminal cases and civil disputes. The Village Courts Act, 2006 contains a Schedule with two parts, which specifies the nature of cases and disputes a Village Court can deal with. At present, there are 4,527 union parishad in Bangladesh. These union Parishads play a vital role in the economic and sociocultural life of the rural people. As the chairmen and members of the union parishads are elected by the local people, they have greater accountability to them the chiefs of the informal Shalish procedures (Shekhar, 2002).

The prevailing restorative model of justice at the local government level in Bangladesh which argues that this model, if adequately activated and reformed, can be a desirable alternative to the formal system of justice for children who come into contact or conflict with the law. This study recognized that the potential of such adjudication bodies as viable alternatives to juvenile courts in protecting the best interests of children, sets out the shortcomings of the local government bodies and the challenges involved in capturing their potential, and finally suggests a number of ways in which the model could be improved. This study argued that local government adjudication bodies can be resorted to as alternative forums to the formal courts and thereby the rights and interests of children can be adequately safeguarded.

This study was an effort to find out how restorative justice could be an effective method for dispute resolution to reduce the backlog and future case loads. Besides, the core challenges of successful restorative justice and some prevention policies to recover drawbacks of the restorative justice in Bangladesh were also studied.

\section{Methodology}

Data and information for this study had been collected from various secondary sources. Such as research journal articles, research reports, and prominent books which explore the effectiveness of restorative justice. Data were analyzed through descriptive methods and thematic analysis to update the existing policy of the government.

\section{Finding and Analysis}

\subsection{Effectiveness of Village Court as a Form of Restorative Justice}

People prefer village court for various reasons such as lower distance, easy to access to the justice, familiarity with village court members and speedy for disposal. But less than $43.33 \%$ go to the village court for its easiness to access to the local justice. Ensuring access to justice is the main prerequisite of good governance. An accountable and efficient justice sector promotes the rule of law and enhances human rights; contributes to the rise of public trust and confidence in justice system which strengthens good governance. It is revealed by research and media reports that 
the formal justice sector is in tremendous pressure with much workload, inadequate number of officials and staffs to dispose the cases (Siddiqui, 1995).

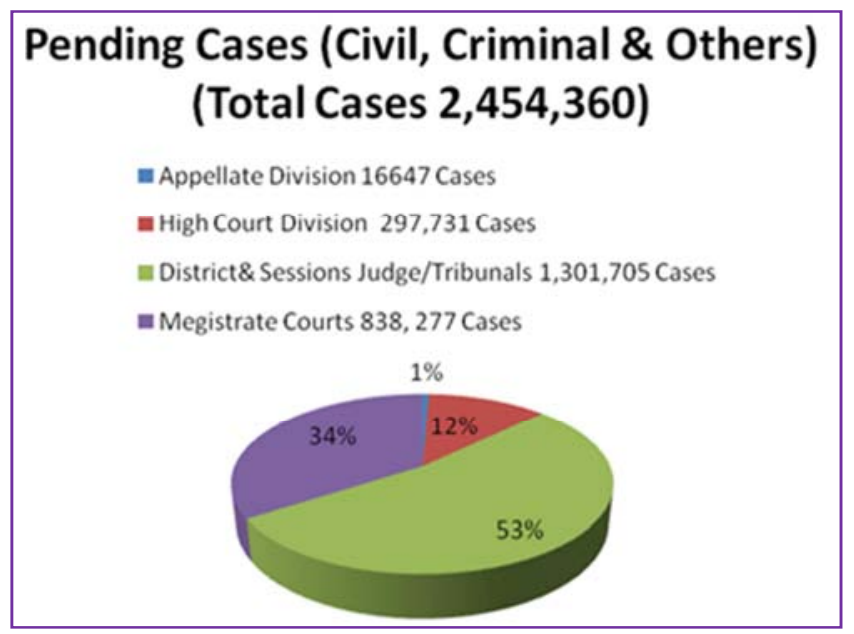

(Source: www.biac.org.bd2014/01/02)

Figure 1. Pending cases (Civil, Criminal, and Others) in Bangladesh as on 2014.

According to Figure 1 statement, in 2014, the number of total pending cases in the Appellate division was 16647 cases, in High court Division were 297,731 cases, in the District Judge Court were 1,301,705 cases and in the Magistrate Courts were 838,277 cases in Bangladesh. So, all these pending cases are creating huge backlog cases which deny proper justice procedure and questioning the accountability of laws.

\subsection{Pressure of Backlog Cases in Bangladesh}

In 2013 18,348 cases were reported and 15,276 resolved on average with a 28 day trial time per case. A total of 13,174 of these decisions have been implemented. Assisting reduce the burden on district courts the number of cases transferred from these courts is 2,776 demonstrating stronger embedding of the culture of village courts in the legal architecture and greater willingness of established courts to redirect cases to local justice structures (Sarker, 2013).

A total of 1,083,827 cases were filed with all the courts and a total of 948,689 cases were disposed in 2011. In that year, the Appellate Division had disposed of 1,859 cases, as 9,141 cases were filed with this division, and 12,441 cases along with the previous cases were pending with it. The High Court Division had disposed of 68,425 cases as 45,084 cases were filed with this court and total 279,923 cases were pending with this court in 2011. The District and Sessions judges' courts had disposed of 207,477 cases, as 327,759 cases were filed with those courts and a total of 1,076,164 cases along with previous cases were remaining pending with these courts in 2011. A total of 706,061 cases were filed with the magistrates' courts across the country in 2011. The magistrates' courts had disposed of 671,628 cases. Earlier in 2010 , the number of total disposal of cases was 1,583. The District and Sessions Judges' courts across the country had disposed of 281,251 cases, as 362,563 cases were filed in 2010. The magistrates' courts had disposed of $1,061,252$ cases, as $1,167,335$ cases were filed in those courts the same year. At the end of 2010, the number of total pending cases at the magistrates' courts was 1,942,163 (www.thedailystar. 2013/03/18). So, all this information shows that the number of disposal of cases are not in satisfactory level and gradually every year the number of Backlog cases is increasing in an alarming rate in Bangladesh.

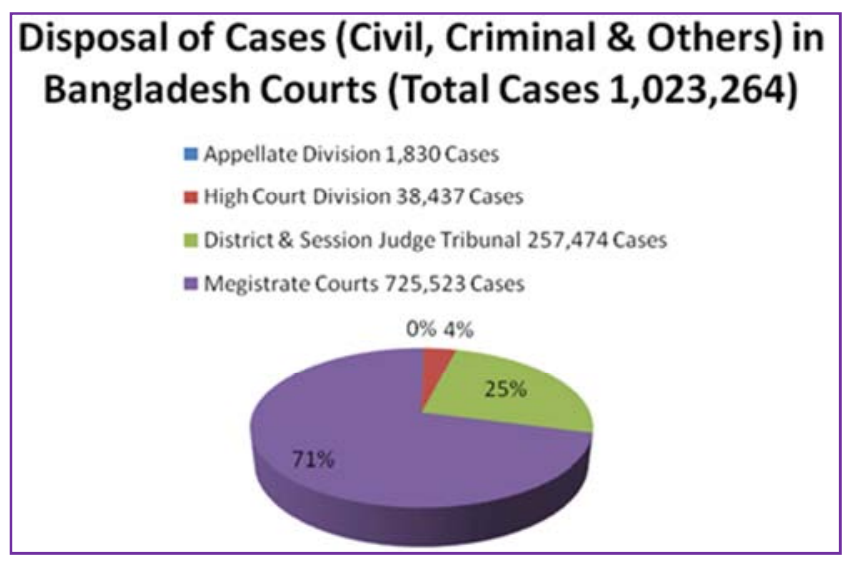

(Source: www.biac.org.bd 2014/01/02)

Figure 2. Disposal of Cases (Civil, Criminal, and Others) in Bangladesh as on 2014.

Figure 2 represents that, in 2014, the number of total disposal of cases in the Appellate division was 1,830 cases, in High court Division were 38,437 cases, in the District Judge Court were 2,57,474 cases and in the Magistrate Courts were 725,523 cases in Bangladesh. Reforms have been instituted in the Bangladesh legal system, but our courts continued to be over-burdened: despite disposal of 1,023,264 cases in 2012, still pending 2,454,360 cases on 1 st January 2013. Of the pending cases, 963,081 cases were of civil nature; many of these cases could be disposed of using ADR methods, without taking recourse to courts. Under this circumstance, alternate institutional avenues for settlement of business disputes had become vital. So, a huge backlog of criminal cases may be reduced if the government can amend the Criminal Procedure of Code to introduce alternative dispute regulation (ADR) for disposing of criminal cases through compromise outside the court. Village court may work as alternative way to reduce pending civil and criminal cases in Bangladesh.

\subsection{Necessity of Restorative Justice in the Society}

\subsubsection{Need of Family or Community Group Conferencing}

It is justified in a restorative perspective as a method of addressing the harm experienced by communities when a crime occurs. However, it can be used instead for retributive reasons or as a means of rehabilitating the offender. What distinguishes its use as a restorative response in the form of family discussion or community conference is the attention given to identifying the particular harm suffered by the 
society as a result of the offender's crime, and the effort to ensure that the offender's community service repairs that particular harm. So, for example, offenders who put graffiti on buildings in a neighborhood can be given the community service of removing graffiti from buildings in that neighborhood. We may follow the community service programs in Africa build on customary processes for making amends, thus addressing community concerns and easing the offender's reintegration into the community (Hossain, 2012).

Restorative justice process brings together the victim, offender, and family, friends and key supporters of both in deciding how to address the aftermath of the crime. The goals of conferencing includes giving the victim an opportunity to be directly involved in responding to the crime, increasing the offender's awareness of the impact of his or her behavior and providing an opportunity to take responsibility for it, engaging the offenders' support system for making amends and shaping the offender's future behavior, and allowing the offender and the victim to connect to key community support. Such conferencing was adapted from Maori traditional practices in New Zealand, where it is operated out of the social services department, and was further modified in Australia for use by police. It is now in use in North America, Europe, and southern Africa in one of those two forms. It has been used with juvenile offenders and with adult offenders. Research on such programs shows very high degrees of satisfaction by victims and offenders with the process and results (Bazemore and Umbreit, 1995).

\subsubsection{Impact of Restorative Justice on Reoffending}

While reducing reoffending is not the only goal of restorative justice, it is critical to be confident that restorative justice does not lead to increase in reoffending. Reducing recidivism is anticipated as an outcome due to the engagement of informal social controls through the inclusion of family, supporters and community representatives (Nielsen, 1999) and the impact of meeting one's victim face to face (Siddiqui, 1995). Informal social control is widely believed to influence offending. Hirschi's (1969) social control theory was grounded in the belief that bonds with prosaically values, people and institutions prevent people from engaging in criminal behavior. The social bonds required to prevent rule-breaking are achieved through four elements commitments, attachments, involvements and beliefs. In essence, the poor opinion that friends and families may have of an individual's deviant behavior has the effect of inhibiting rule-breaking. Once offending has taken place, Braswell (2014) posits that reiterative shaming inhibits further offending.

Restorative justice processes are also underpinned by reiterative shaming theory. Conferencing, one of the more common forms of restorative justice, is thought to be more effective than court processes in reducing reoffending due to the different stigmatizing effects of each. That is, stigmatizing of offenders in traditional processes serves only to reinforce their deviant behavior, whereas conferences stigmatize the behavior and not the individual, the importance of which is set out in Braithwaite's theory of reiterative shaming (Crisostomo, 2008). As evident in the brief summaries of evaluations of the various restorative justice programs reviewed in the previous, evidence of the effectiveness of restorative justice is mixed. This thinking should be followed by Bangladesh to prevent the reinforcement of deviant offender which may reduce our pressure of cases in all types of courts.

\subsubsection{Impact of Restorative Justice on Victim Satisfaction}

Historically, restorative justice was once widely used as a response to wrongdoing. As crimes committed against an individual became crimes against the 'King's peace' and later, against the state, the role of the victim was eroded (Ameen, 2005). The reintroduction of restorative justice practices alongside the adversarial system is seen as redressing the balance. Although victims are considered to play a central role in restorative justice processes, this has been disputed. A range of indicators (low number of victims attending conferences, use of restorative justice for 'victimless' crimes such as graffiti, eligibility criteria being based on offenders) that restorative justice is primarily about reforming offenders than repairing the harm caused to victims (Ness, V. and Strong. (2015)). The benefits of restorative justice are not restricted to offenders alone. In an analysis of what victims need from restorative justice, Mc Cold (2001), found that victims in the traditional criminal justice system commonly experience: a lack of attention to 'non-material dimensions of victimization', for example, anger, fear and mistrust; no focus on repairing the injury caused by crime; failure of the criminal justice system to clearly communicate with victims regarding the status of the case; failure to provide victims with a legitimate and active role when dealing with offences committed against them; and perceptions of a lack of procedural fairness and dissatisfaction with outcomes due largely to having been excluded from the decision-making process.

\subsection{Challenges of Restorative Justice}

\subsubsection{Limited Coverage and Jurisdiction}

At present, only two types of local government adjudication bodies are legally authorized to deliver restorative justice: village courts within the limits of union parishad and dispute conciliation boards within the limits of paurashava. Areas covered by city corporations and cantonment boards are outside the purview of local government adjudication (Saadi et al. 2014).

The list of offences currently subject to the jurisdiction of village courts and dispute conciliation boards is unreasonably short. Moreover, the choice of offences reflects no rational basis. It contains several cognizable offences, some of which are of a serious nature, but fails to contain many noncognizable petty offences. This anomaly needs to be rectified. Further, section 16 of the Village Courts Act, 2006 as well as section 5(2) of the Dispute Conciliation (Municipal Areas) Board Act, 2004 allow transfer of cases from local government adjudication bodies to the formal criminal courts 
in the 'interests of justice'. Any such transfer of a case wherein a child is accused can cause double trouble to the accused and thus jeopardize the interests of children. Another area of concern is linking of offences in a case. The Dispute Conciliation (Municipal Areas) Board Act of 2004 expressly provides that if an offence amenable to the jurisdiction of the board is committed along with another offence not amenable to its jurisdiction and joint trial becomes necessary, the board shall not exercise its jurisdiction to try the offence (section 5(1)). Although the Village Courts Act of 2006 does not contain any such provision, it has been held by the highest court of the country that if in a case, an offence trouble by the village court is joined with an offence tradable by the magistrate, the case shall be tried by the magistrate and not by the village court (Abul Kalam and others, vs. Abu Daud and another, 4 MLR (AD) (1999) 4145 BLC (AD) (2000) 19). Thus, if a child commits any offence within the jurisdiction of local government adjudication bodies can easily be forced to face formal courts by mere allegation of another offence outside those bodies' jurisdiction (Khan and Rahman, 2009).

\subsubsection{Power of the Police to Investigate Cognizable offences}

As noted above, village courts and dispute conciliation boards are authorized to deal with some cognizable offences. In the case of these offences, police retain the power to investigate (The Village Court Act, 2006 (Act No. 19 of 2006), section 17; The Disputes Conciliation (Municipal Areas) Board Act, 2004 (Act No. 12 of 2004), section 18). Therefore, since the power of investigation, so far as cognizable offences are concerned, includes the power to arrest an accused without the authorization of any court (Code of Criminal Procedure 1898 (Act V of 1898), section 156), there is the possibility that a child accused of any of those offences can be arrested by the police (Rahman, 1985).

\subsubsection{No Special Treatment for Children}

One of the shortcomings of the Village Courts Act 2006 and Dispute Conciliation (Municipal Areas) Board Act, 2004 is that these two Acts do not differentiate a child accused from an adult accused in terms of their treatment. The union bench established by the Bengal Village Self-Government Act, 1919 was authorized to release an offender after due admonition or on probation considering his conviction record, age, character, and antecedents (section 72A). Also, a child, if tried or dealt with by the formal courts in accordance with the Children Act, 1974, can be released after due admonition or on probation (section 53(1)). But these two adjudication options, admonition and probation, are not available to local government bodies (Sarker, 2013).

\subsubsection{Care and Protection of Destitute and Neglected Children}

Part V of the Children Act, 1974 (Act No. XXXIX 1974) empowers the juvenile courts to take necessary measures in respect of destitute and neglected children (sections 32-33). However, this jurisdiction of the juvenile courts is rarely exercised. In fact, societal aspects of the issue of care or protection of destitute and neglected children are not easy matters for the formal courts to address in a successful manner. As an alternative, therefore, vesting this power in the local government adjudication bodies could be a good option. However, at present these adjudication bodies are not so empowered (Mc Cold, 2001).

\subsubsection{Malfunctioning and Non-functioning}

The preoccupation of local government bodies with issues other than dispute resolution, especially service delivery, has gradually diverted their focus from dispensing justice (Lambson, 2015). Consequently, village courts have now in most cases disappeared. This leaves the traditional informal shalish as the dominant means of adjudication for small-scale civil and criminal disputes. An opinion survey conducted by Democracy Watch reveals that regarding village courts, only $6.8 \%$ of the respondents said they were functioning, $71.0 \%$ said they were beset with favoritism, and $22.2 \%$ said they were inactive (Meadows, 2012).

Similarly, village courts do not appear to have attracted significant community support. One study on several village courts found that only twenty percent of cases within their jurisdiction actually reach these courts, while findings from a participatory rural appraisal conducted under a UNDP study in a village in Tangail district revealed a strong preference for shalish compared to the village court (Ness and Strong, 2015).

The fact that village courts or conciliation boards are expected to discharge judicial functions and administer justice in accordance with law requires that personnel serving on the adjudication panel have basic legal training. However, at least one study shows that village court functionaries lack knowledge about the procedure and norms prescribed for village courts. It also found that the casual nature of shalish, which had been followed for many years, is still being practiced. Another study shows that the village court functionaries are not serious about the working of the village courts (Mentle, 2005).

\subsubsection{Lack of Legal Awareness of the Service Seekers and Providers}

The lack of legal awareness (capacity to understand the legal rights, remedies and responsibilities) of both the service seekers and providers, limited jurisdiction of Village Court, lack of financial and human resources of the Union Parishad. Lack of awareness of the mass people about village court is the major limitation of village court to work actively. Both the service seekers and providers have little or no knowledge about Village Court. During the time of the study, visibly there was no awareness program or local initiatives at the local/national level to make people aware about village court. Also no NGO initiatives were observed there to help this institution. The scenario is completely opposite in the project area. The other concerned authorities such as the local police, UNOs who are legally designated and closely work with the UPs are also not well aware about the village court. In most of the cases the court decorum was not maintained. It was 
observed that, disputes related to land and property is the source of most of the conflicts in rural area. Violence against women and family dispute is also a major problem (Morris and Maxwell, 2004).

\subsubsection{Lack of Monitoring and Supervision of the Court Activities}

Lack of proper monitoring and supervision of the higher authority is essential to formidable barrier in dispensing justice locally. Monitoring and supervision mechanism is very weak in both the areas. UP chairman don't send the reports and returns to the concerned authority regularly. After the separation of judiciary from the executive in 2007, UNOs and DCs/ District Magistrate have little or no control over the judicial activities of the village court. Judicial magistrates, judges and police are also unaware about the village court and local police regularly entertains cases that fall under the jurisdiction of village court (McLaughlin, 2003).

\subsubsection{Negative Attitudes and Perceptions Towards Legal Institutes}

Victim's first preference for seeking justice is Shalish which is still the most powerful means for dispute resolution in rural Bangladesh. If settlement of disputes fails at Shalish, the victims involve the Union Parishad or go to the police or formal courts. Again, village politics is also an important factor that impedes functioning and constituting of the village courts. Most of the service seekers and providers agreed noted that due to the complex socio-economic and political realities, they sometimes do not get justice. It was also observed that the people's confidence has to be restored on the chairman and members for the functioning of Village Court (Rahman, 1985).

\subsubsection{Absence of Legal Aid and Support Mechanism of the NGOs}

When government starts activating a village court program as facilitator started functioning in the project area (kashiani). The scenario is complete opposite outside the project area (Jhawgara). The UP of the project area (Kashiani) is heavily dependent on NGO assistance. Though NGO assistance is essential to make people aware about their rights and privileges but too much dependency is also a vital impediment for the institutionalization and successful working of VC (Sarker 2013).

\subsubsection{Village Court as an Unfunded Mandates on Local Governments}

Village Court outside the project area has not received any fund from Local Government Ministry or from Upazila Parishad. Outside the project area all VC runs without a fulltime court assistant and the UP secretary usually performs this task who thinks that it is beyond their ordinary job descriptions. The members and chairman of a Union Parishad serve in the Village Court as a part of their functions in the Union Parishad. But considering their overall responsibilities as members and chairmen of the Union Parishad, their salary or honorarium is too poor. The resources and facilities in the project aided courts have positive effect on the quality of justice dispensed. The UP chairmen and members are interested to perform judicial activities which by law have vested on them but at the same time in the absence of the government sponsored project intervention or NGO initiatives they cannot perform it (Siddiqui, 1995).

\subsubsection{Lack of Competencies of the UP Officials}

The UP Chairman, secretary and UP members have a considerable level of education which is favorable in dispensing justice. The UP officials have the lack of training, lack of the machinery, and more than anything else, for lack of the understanding of what it means to make a full and complete record. The record management of the village courts is awfully poor (Shekhar, 2002).

\subsubsection{Complexity and Lack of Clarity of the Act, Rules and Procedures}

For both the service providers and seekers the existing Village Court Act, 2006 is difficult thunder sand. Again, under the Village Court rules 1976, a Village court has to preserve and use eleven kinds of forms for use as register of cases, summons to respondent and witness, decrees and orders, receipt and register of fines and also half yearly report return which makes the whole process complicated. Narrow jurisdiction of $\mathrm{VC}$ allows and encourages both the service seekers and providers to take resort to Shalish or to go to police and formal court. Financial jurisdiction of $\mathrm{VC}$ is limited and most of the case approaches to the $\mathrm{VC}$ are beyond its jurisdiction. Though the offences like dowry and violence against women is very common in rural Bangladesh but $\mathrm{VC}$ has no jurisdiction to trial cases related to domestic violence or dowry (Wahhab, 2009).

\section{Conclusion}

Restorative justice has burst on the international scene as an umbrella concept and social movement. The Village Court is a form of restorative justice which is developed to reduce huge case load of the formal justice system. Basically it deals with civil cases includes; family matter, land dispute, property crime, marriage and divorce etc. On the other hand, some criminal cases like theft, eve teasing, rape, cheating, coalition, mischief, etc. are also solved by village court. In Bangladesh, the formal justice system is under tremendous pressure for huge caseloads and vastly overstretched human resources mean that the backlog of cases at present stands at nearly half a million. For its lower cost, speedy disposal and known person come together with justice process rural people go to Village Court. But the satisfaction level of its justice is under below standard which brings the parties to appeal to higher court or complain to police station. Consequently, the risk factors of bellow standard satisfaction are biasness of the judges; deny of accepting cases, absence of opposite party, contamination of evidence, etc. So to observe an effective Village Court as a form of restorative justice, some necessity reformation should be taken place without any delay. 


\section{References}

[1] Ameen, N. (2005), Dispensing Justice to the Poor: The Village Court, Arbitration Council vis-à-vis NGO Mediation, The Dhaka University Studies (Journal of the Faculty of Law), Part - F, 16 (2).

[2] Braswell. M. (2014), Restorative Justice and Peacemaking, Journal of Theoretical and Philosophical Criminology.

[3] Bazemore, G and Umbreit, M S (1995), Rethinking the Sanctioning Function in Juvenile Court: Retributive or Restorative Responses to Youth Crime, Crime \& Delinquency, $41(3)$.

[4] Crisostomo, R. (2008), The Effectiveness of Restorative Justice Practices: How to Restore Justice for At-Risk Youth, California.

[5] Hassan, M. (2006), Access to Formal and Informal Justice System and Legal Empowerment Strategies in Bangladesh, background paper for the Bangladesh Gender Assessment, World Bank, Dhaka.

[6] Hossain, M. B. (2012), Dispensing Justice Locally: A Study of Two Village Courts in Bangladesh, North South University.

[7] Khan, B. U. and Rahman, M. M. (2009), Local Government Level Restorative Adjudication: An Alternative Model of Justice for Children in Bangladesh, Commonwealth Journal of Local Governance Issue 4.

[8] Kamruzzaman M. (2015), Child Victimization at Working Places in Bangladesh. American Journal of Applied Psychology, 4(6): 146-159.

[9] Lambson, H. S. (2015), Evaluating a Native American Restorative Justice Practice in a State Criminal Court Setting, Brooklyn.

[10] Kamruzzaman M. (2017), Prisoners' Posture on Prison: A Criminological Study. American Journal of Information Science and Computer Engineering, 3(1): 7-13.

[11] Meadows, etal. (2012), Evaluation of the South Yorkshire Restorative Justice Programme Morris, A. and Maxwell, G. (2004), Reforming criminal justice: the potential of restorative justice, Spiger publication.

[12] Mc Cold, P. (2001), Primary Restorative Justice Practices, Hart Publishing, Oxford. McLaughlin, E et al (eds.) (2003), Restorative Justice: Critical Issues, Sage Publications Ltd, London.

[13] Kamruzzaman M and Hakim M A. (2016), Prevalence of Acid Crime Victimization in South Asia: A Review. Journal of Biological and Environmental Engineering, 1(2): 17-22.

[14] Mentle, et al. (2005), Restorative Justice and Three Individual Theories of Crime, Internet Journal of Criminology.

[15] Ness, V. and Strong. (2015), Restoring justice: An introduction to restorative justice, $5^{\text {th }}$ edition, London and New York: Rutledge.

[16] Kamruzzaman M and Hakim M A. (2016), Factors Associated with the Suicidal Tsunami as a Mental Illness: Findings from an Epidemiological Study. American Journal of Environment and Sustainable Development, 1(1): 1-5.
[17] Rahman, M M. (1985), A Study of Two Village Courts, The Journal of Local Government, 14(2).

[18] Saadi, A etal. (2014), Effectiveness of Village Court in Bangladesh: A Study in Tangail District, Bangla vision, 13(1).

[19] Kamruzzaman M et al. (2016), Plight of Youth Perception on Cyber Crime in South Asia. American Journal of Information Science and Computer Engineering, 2(4): 22-28.

[20] Sarker, N. I. (2013), An Evaluation of Village Court: A Study on Selected Village Courts Bangladesh, BRAC University.

[21] Shekhar, B (2002), Restorative Justice - An Alternative to Existing Retributive Justice System, Social Defence, 53(152).

[22] Kamruzzaman M. (2015) Dowry related Violence against Rural Women in Bangladesh. American Journal of Psychology and Cognitive Science, 1(4): 112-116.

[23] Siddiqui, K (ed.) (1995), Local Government in South Asia- A Comparative Study, University Press Limited, Dhaka.

[24] Kamruzzaman M and Hakim M A. (2016), Basic Rights on the Wane, Human Rights on Brown Study: A Case Study on Thrown Away Children in Bangladesh. International Journal of Environmental Planning and Management, 2(4): 29-35.

[25] Kamruzzaman M. (2016), Interreligious Marriage in Bangladesh: From Human Rights Perspective. International Journal of Education, Culture and Society, 1(2): 44-51.

[26] Kamruzzaman M and Hakim M A. (2015), Child Criminalization at Slum Areas in Dhaka City. American Journal of Psychology and Cognitive Science, 1(4): 107-111.

[27] Kamruzzaman M. (2016), Formalin Crime in Bangladesh: A Case Study. European Journal of Clinical and Biomedical Sciences, 2(5): 39-44.

[28] The Daily Star, June 8, 2013 Retrieved at April 2, 2017 from www.thedailystar.net/default/files/beta2/uploads/2013/03/18ca ses04.jpg

[29] Wahhab, M A. (2009), Gram Adalat in Bangladesh: Theory and Practice, in Singh, A and Zahid, N A (eds.), Strengthening Governance through Access to Justice, PHI Learning Pvt. Ltd, New Delhi.

[30] Kamruzzaman M. (2016), A Criminological Study on the Dark Figure of Crime as a Socio-ecological Bulk of Victimization. American Journal of Business, Economics and Management, 4(4): 35-39.

[31] Kamruzzaman M and Das SK. (2016), The Evaluation of Human Rights: An Overview in Historical Perspective. American Journal of Service Science and Management, 3(2): $5-12$.

[32] Kamruzzaman M and Hakim M A. (2016), Prostitution Going Spiral: The Myth of Commercial Child Sex. International Journal of Biomedical and Clinical Sciences, 1(1): 1-6.

[33] Kamruzzaman M and Hakim M A. (2016), Socio-economic Status of Slum Dwellers: An Empirical Study on the Capital City of Bangladesh, American Journal of Business and Society, 1(2): 13-18.

[34] Kamruzzaman $\mathrm{M}$ et al. Patterns of Behavioural Changes Among Adolescent Smokers: An Empirical Study. Frontiers in Biomedical Sciences 2016, 1(1): 1-6. 
[35] Das SK, Khan M B U and Kamruzzaman M. (2016), Preventive Detention and Section 54 of the Code of Criminal Procedure: The Violation of Human Rights in Bangladesh. American Journal of Business and Society, 1(3): 60-67.

[36] Kamruzzaman $M$ et al. (2016), Extrajudicial Killings: The Violation of Human Rights in Bangladesh. International
Journal of Environmental Planning and Management, 2(4): 20-28.

[37] www.biac.org.bd/wp-content/uploads/2014/01/fav.ico

[38] www.bbs.gov.bd 